\title{
Penerapan Website Sistem Pengajuan Cuti Pegawai Pada Kantor Kecamatan Ciawi Bogor
}

\author{
Susi Susilowati ${ }^{1}$, Rahmi Widiana ${ }^{2}$ \\ Program Studi Sistem Informasi Universitas Bina Sarana Informatika \\ Jl. Kramat Raya No.18 Ringroad Barat, Cengkareng, Jakarta Barat \\ susi.sss@bsi.ac.id,rahmiwidiana99@gmail.com
}

\begin{abstract}
Limitations of the process on filing employee leave at the Ciawi Bogor sub-district office tend to be ineffective and inefficient so that in the process it makes both parties (employees and operators) have a difficulty. In addition to the leave filing files that are piled up, sometimes the operator forgets to process when there are employees who apply for leave. The research objective is to produce a web-based leave filing program so as to make it easy for users to apply for and process leave. The method of developing a software system uses the waterfall model. The results of the study in addition to displaying information about office activities or staffing on the main page, there are also facilities for filing leave, and changing the status of leave applications. Through this website employees had a view of information about the office activities and make the leave submission process online.
\end{abstract}

Keywords: the leave filing files, employees, waterfall model.

\begin{abstract}
Abstrak
Keterbatasan mengenai proses pengajuan cuti pegawai di kantor kecamatan Ciawi Bogor cenderung tidak efektif dan efisien sehingga dalam prosesnya tersebut membuat kedua belah pihak (pegawai dan operator) merasa kesulitan. Selain berkas pengajuan cuti yang tertumpuk, terkadang operator lupa untuk memproses ketika ada pegawai yang mengajukan cuti. Tujuan penelitian menghasilkan program pengajuan cuti berbasis web sehingga memberikan kemudahan kepada pengguna dalam mengajukan dan memproses cuti. Metode pengembangan sistem perangkat lunak menggunakan model waterfall. Hasil penelitian selain menampilkan informasi seputar kegiatan kantor atau kepegawaian di halaman utama tersedia juga fasilitas untuk melakukan pengajuan cuti, serta perubahan status pengajuan cuti. Melalui website ini pegawai dapat melihat informasi seputar kegiatan perkantoran dan melakukan proses pengajuan cuti secara online.
\end{abstract}

Kata kunci: Pengajuan Cuti, Pegawai, Model Waterfall.

\section{PENDAHULUAN}

Perkembangan teknologi sekarang ini membawa dampak yang baik bagi manusia, dalam hal ini khususnya bagi sebagian besar perusahaan, dimana teknologi dapat mempermudah kegiatan manusia. Salah satu implementasi teknologi informasi yang sangat banyak diterapkan pada perusahaan yaitu sistem informasi kepegawaian, dimana salah satu nya adalah aplikasi pengajuan cuti. Terdapat penelitian tentang pengajuan cuti pegawai, namun hasil penelitian tersebut belum menyediakan kesempatan bagi pegawai untuk mengajukan cuti secara online. Penelitian tentang aplikasi pengajuan cuti pegawai secara online penting dilakukan karena memberikan manfaat dalam memberikan informasi dengan cepat, dan memberikan kemudahan bagi pegawai untuk dapat mengajukan cuti dan mengakses informasi cuti pegawai. Aplikasi web untuk pengajuan cuti 
pegawai secara online yang dihasilkan dapat memberikan solusi bagi permasalahan yang ada. Maka dengan adanya aplikasi ini instansi terkait dapat memanfaatkannya untuk meningkatkan kinerja dan efisiensi waktu dalam kegiatan di bagian kepegawaian yaitu pengajuan cuti pegawai secara online[1].

Cuti merupakan salah satu hak pegawai. Cuti dapat digunakan oleh pegawai untuk tidak masuk kerja dengan alasan tertentu, misalkan refreshing, istirahat sakit, melahirkan, menunaikan kewajiban agama, dan keperluan lain sesuai dengan ketentuan cuti pada masing-masing organisasi[2]. Pengajuan cuti pegawai pada Kantor Kecamatan Ciawi masih dilakukan secara manual dimana ketika pegawai memiliki permintaan untuk mengajukan surat permohonan cuti kepada Operator Kepegawaian hanya sebatas melalui permintaan langsung atau melalui surat yang akan di proses oleh Operator Kepegawaian. Hal tersebut menyebabkan kesulitan dalam pencarian data surat ketika surat permintaan tersebut menjadi tertumpuk,atau Operator lupa bahwa ada pegawai yang meminta untuk dibuatkan Surat Permohonan Cuti tersebut.

Dalam permasalahan tersebut yang sangat diperlukan adalah media yang praktis dan mudah dalam penggunaannya serta sudah banyak diterapkan oleh banyak instansi pemerintahan lain yaitu sebuah media online seperti website untuk membantu proses pengajuan cuti khususnya para Pegawai. Dimana di dalam website ini berisikan informasi berupa formulir pengajuan cuti.

\section{METODOLOGI PENELITIAN}

Metode yang digunakan pada pengembangan perangkat lunak ini menggunakan model waterfall. Model ini bersifat linear dari tahap awal pengembangan sistem yaitu tahap perencanaan sampai tahap akhir pengembangan sistem yaitu tahap pemeliharaan. Tahapan berikutnya tidak akan dilaksanakan sebelum tahapan sebelumnya selesai dilaksanakan dan tidak bisa kembali atau mengulang ke tahap sebelumnya[3]. Model Waterfall terbagi menjadi 4 tahapan seperti yang digambarkan dalam bagan berikut[4]:

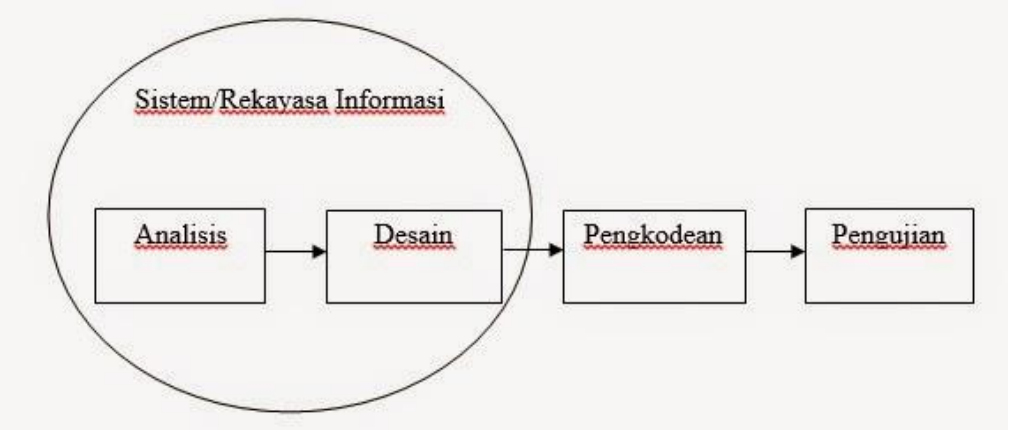

Gambar 1. Model Pengembangan Perangkat Lunak Waterfall 
a) Analisis kebutuhan perangkat lunak

Proses pengumpulan kebutuhan dilakukan secara intensif untuk menspesifikasikan kebutuhan perangkat lunak seperti yang dibutuhkan oleh user. Spesifikasi kebutuhan perangkat lunak pada tahap ini perlu didokumentasikan.

b) Desain

Desain perangkat lunak adalah proses multi langkah yang fokus pada desain pembuatan program perangkat lunak termasuk struktur data, arsitektur perangkat lunak, representasi antarmuka, dan prosedur pengkodean. Tahap ini mentranlasi kebutuhan perangkat lunak dari tahap analisis kebutuhan ke representasi desain agar dapat diimplementasikan menjadi program pada tahap selanjutnya. Desain perangkat lunak yang dihasilkan pada tahap ini juga perlu didokumentasikan.

c) Pembuatan kode program

Desain harus ditranlasikan kedalam program perangkat lunak. Hasil dari tahap ini adalah program komputer sesuai dengan desain yang telah dibuat pada tahap desain.

d) Pengujian

Pengujian fokus pada perangkat lunak secara dari segi logik dan fungsional dan memastikan bahwa semua bagian sudah diuji. Hal ini dilakukan untuk meminimalisir kesalahan (error) dan memastikan keluaran yang dihasilkan sesuai dengan yang diinginkan.

Sedangkan metode permodelan sistem yang akan digunakan adalah model UML (Unified Modeling Language). Model UML bahasa pemodelan visual yang digunakan untuk menspesifikasikan, menvisualisasikan, membangun, dan mendokumentasikan rancangan dari suatu sistem perangkat lunak[5]. Adapun diagram UML yang digunakan untuk melakukan permodelan sistem pengajuan cuti pegawai kecamatan ciomas bogor adalah :

\section{Activity Diagram}

Menggambarkan workflow (aliran kerja) atau aktivitas dari sebuah sistem atau proses bisnis atau menu yang ada pada perangkat lunak.

2. Use Case Diagram

Menggambarkan pemodelan untuk kelakuan (behavior) sistem informasi yang akan dibuat. Use case mendeskripsikan sebuah interaksi antara satu atau lebih aktor dengan sistem informasi yang akan dibuat.

\section{HASIL DAN PEMBAHASAN}

\subsection{Analisa Kebutuhan Perangkat Lunak}

Analisis kebutuhan perangkat lunak yang dibutuhkan dalam pembuatan website sistem pengajuan cuti pegawai pada kantor kecamatan Ciomas Bogor ini, antara lain : 
1. Kebutuhan Pengguna

Kebutuhan pengguna dalam perancangan ini terbagi menjadi kebutuhan Pegawai dan kebutuhan admin website.

a. Kebutuhan Pegawai

1) Menginput dan melihat data pengajuan cuti yang sudah dilakukan

2.) Pegawai dapat melihat notifikasi pengajuan cuti (disetujui atau tidak).

b. Admin Website

1) Melihat seluruh data pengajuan cuti yang masuk

2) Memproses pengajuan cuti pegawai dengan mengubah status pengajuan menjadi diterima atau ditolak.

3) Mencetak surat pengajuan cuti yang telah disetujui.

2. Kebutuhan Sistem

1) Untuk masuk kedalam sistem, pengguna harus melakukan login terlebih dahulu dan melakukan logout untuk meninggalkan sistem.

2) Sistem dapat menyimpan dan menampilan data pengajuan cuti.

3) Sistem dapat memberikan notifikasi untuk pengajuan cuti yang telah disetujui.

4) Sistem dapat melakukan mencetak surat pengajuan cuti yang telah disetujui.

5) Sistem dapat melakukan mencetak laporan pengajuan cuti.

\subsection{Desain}

\section{A. Desain Sistem}

\section{Usecase Diagram}

Diagram ini menggambaran fungsi-fungsi yang ada dalam website pengajuan cuti pegawai pada kantor kecamatan Ciomas Bogor.

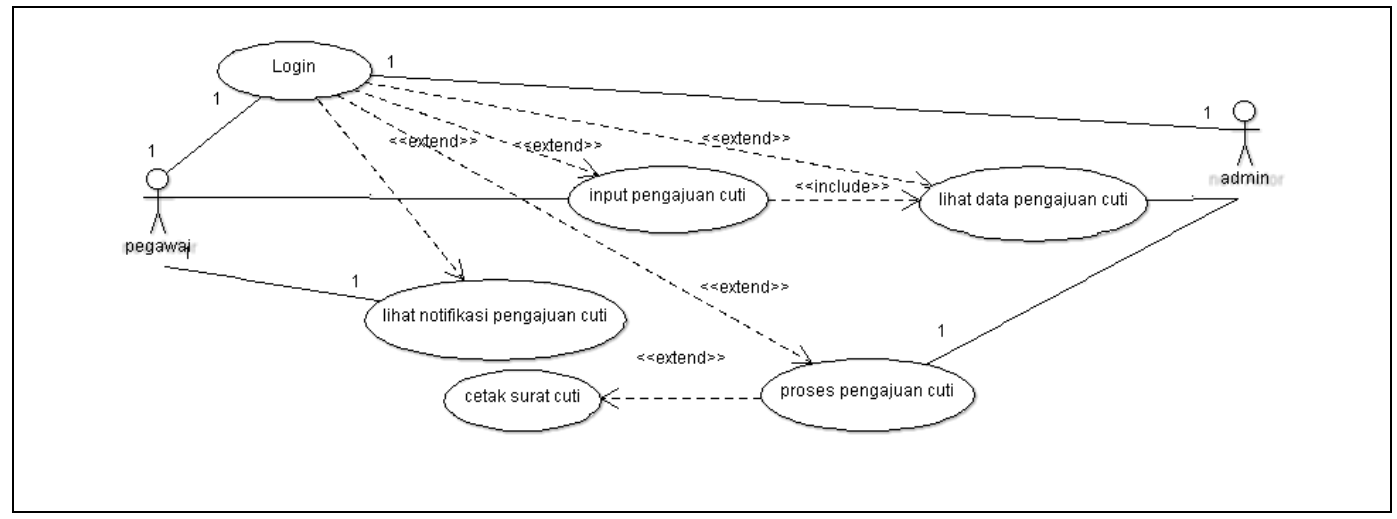

Gambar 2. Diagram usecase pengajuan cuti

\section{Activity Diagram}

a. Activity diagram pengajuan cuti oleh pegawai Diagram ini menggambarkan tahapan kegiatan yang dilakukan oleh pegawai dalam melakukan pengajuan cuti 
Jurnal Sains Komputer \& Informatika (J-SAKTI) Volume 3 Nomor 2 September 2019, pp. 327-336 ISSN:2548-9771/EISSN:2549-7200 http://tunasbangsa.ac.id/ejurnal/index.php/jsakti

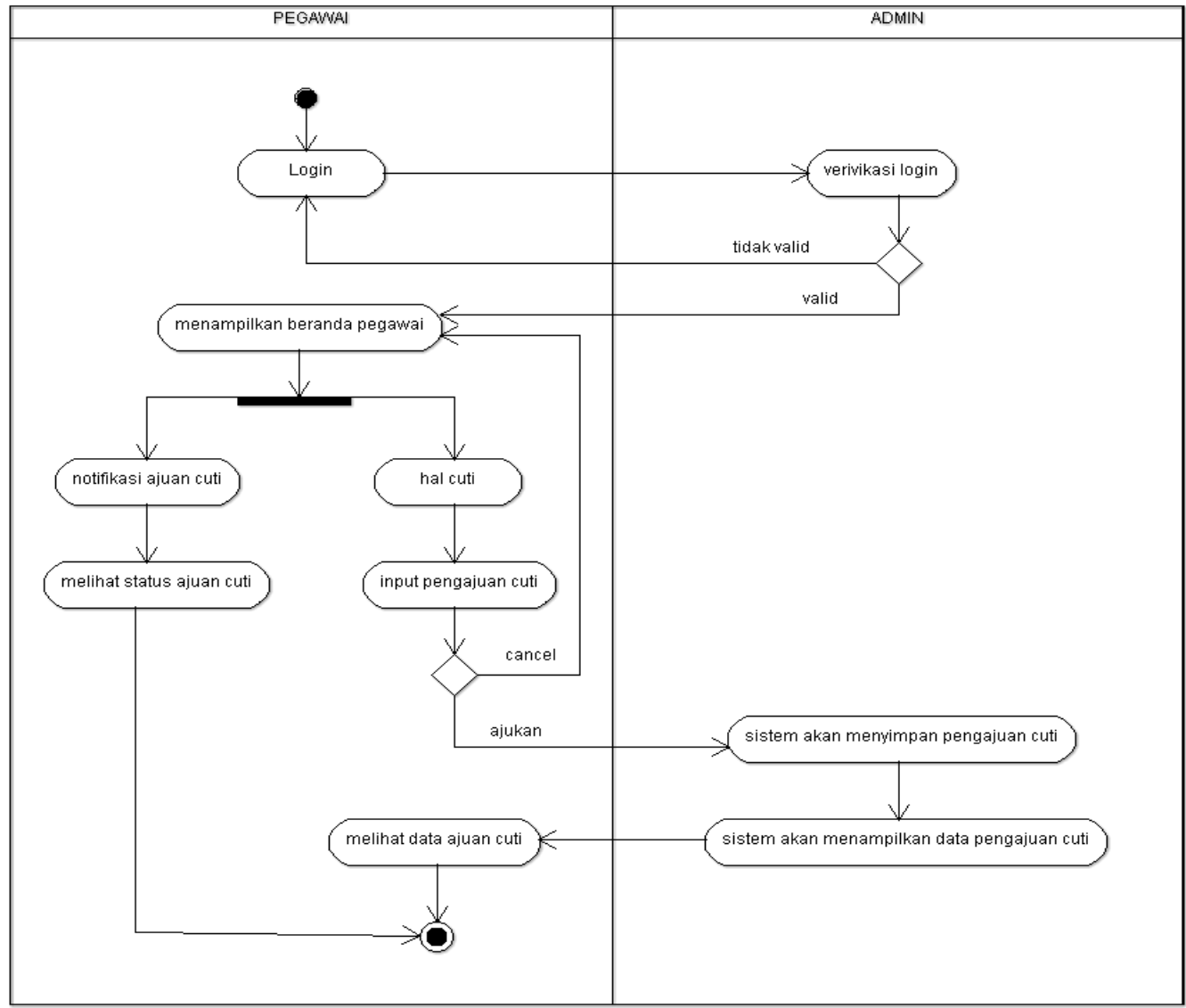

Gambar 3. Diagram Aktivitas Pengajuan Cuti oleh Pegawai

b. Activity diagram proses pengajuan cuti oleh admin Diagram ini menggambarkan tahapan kegiatan yang dilakukan oleh admin didalam memproses pengajuan cuti yang telah dilakukan pegawai. Admin akan memberikan perubahan status ajuan menjadi disetujui atau ditolak. 
Jurnal Sains Komputer \& Informatika (J-SAKTI)

Volume 3 Nomor 2 September 2019, pp. 327-336

ISSN:2548-9771/EISSN:2549-7200

http://tunasbangsa.ac.id/ejurnal/index.php/jsakti

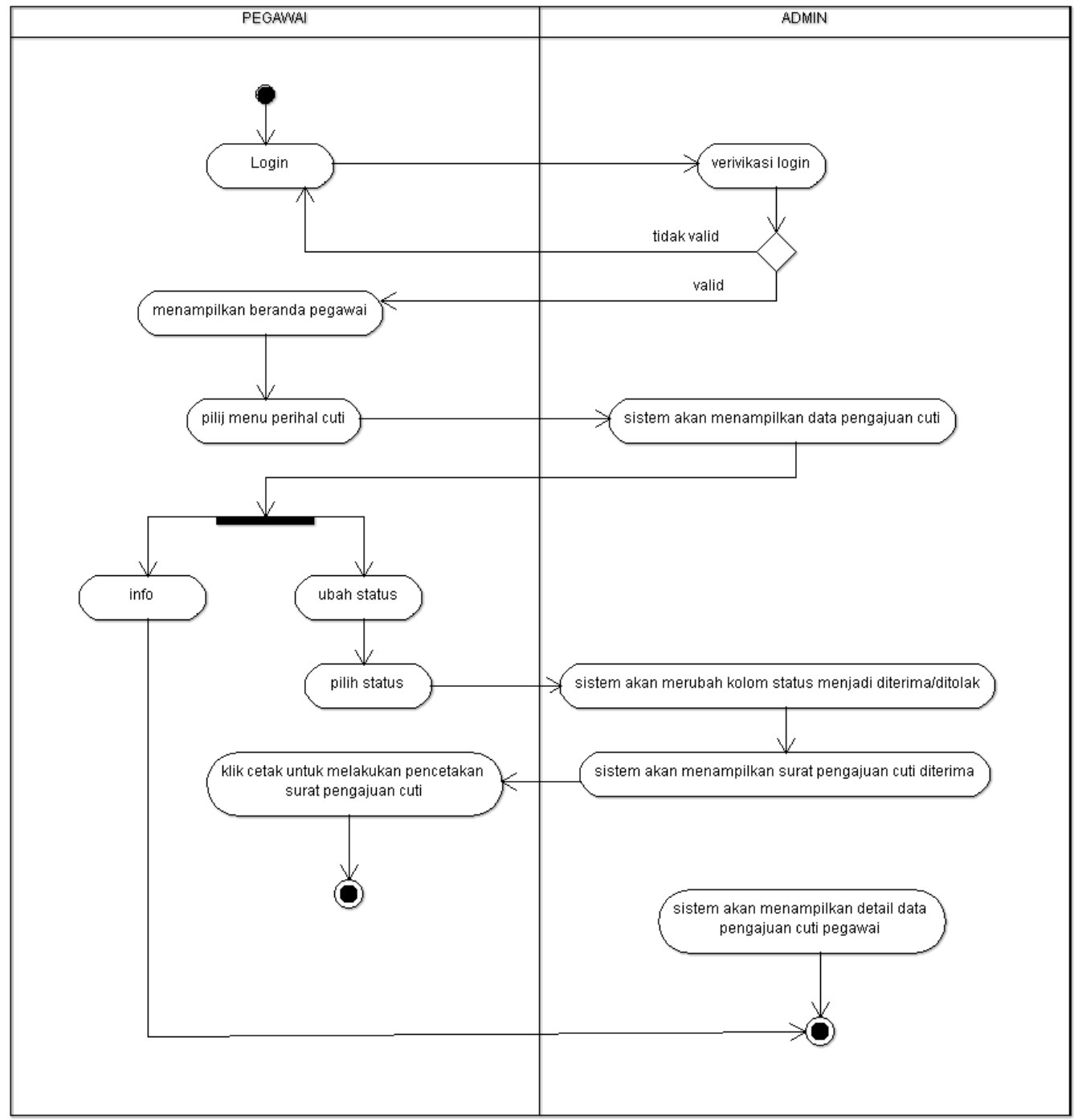

Gambar 4. Diagram Aktivitas Proses Pengajuan Cuti oleh Admin

\section{B. Desain Database}

Desain database penulis gambarkan menggunakan ERD (entity relationship diagram). ERD atau diagram Entitas relasi adalah diagram yang menggambarkan entitas berserta elemen-elemen datanya dan hubungannya (relasi) dengan entitas yang lain. ERD merupakan notasi grafis dalam pemodelan data konseptual yang mendeskripsikan hubungan antara penyimpanan. Dengan ERD kita dapat menentukan data apa saja yang diperlukan, disimpan dalam file apa, dan bagaimanan hubungannya dengan data yang lain dalam basis data yang kita bangun[6]. Adapun database yang digunakan dalam website pengajuan cuti pegawai pada kantor kecamatan ciomas bogor adalah : 
Jurnal Sains Komputer \& Informatika (J-SAKTI)

Volume 3 Nomor 2 September 2019, pp. 327-336

ISSN:2548-9771/EISSN:2549-7200

http://tunasbangsa.ac.id/ejurnal/index.php/jsakti

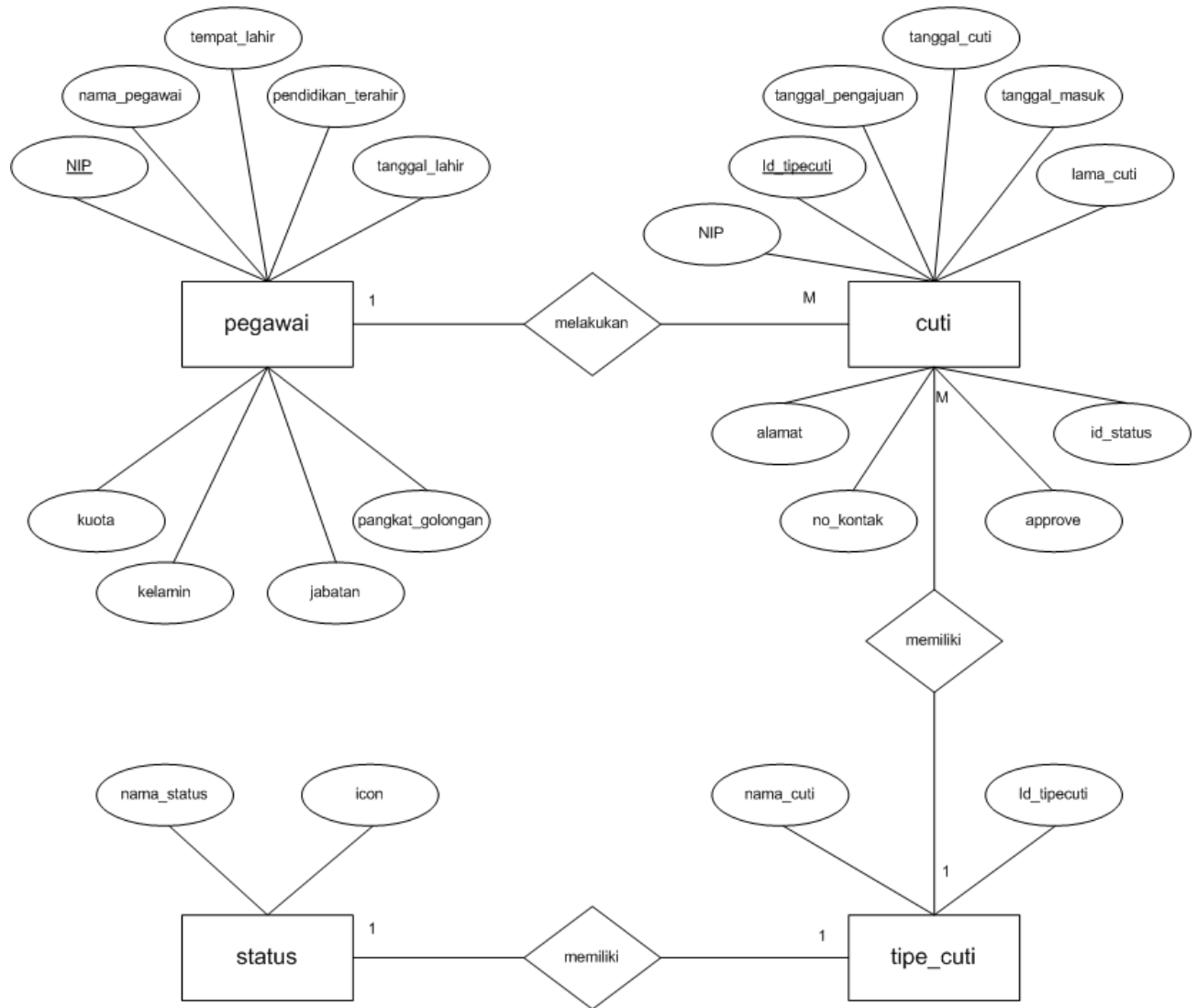

Gambar 5. Entitiy Relationship Diagram (ERD)

\subsection{Implementasi (pembuatan kode program)}

Pada tahapan ini adalah pembuatan program yang digunakan dalam tahapan sebelumnya. Bahasa pemrograman yang digunakan yaitu HTML, JavaScript, dan CSS pada sisi clientside sedangkan untuk serverside menggunakan PHP serta pembuatan databasenya menggunakan MySQL. Dan software teks editor yang digunakan yaitu Sublime Text.

A. Implementasi rancangan halaman pegawai

1. Halaman Pengajuan cuti

Halaman ini berfungsi untuk melakukan proses pengajuan dan melihat data pengajuan cuti yang telah diajukan.

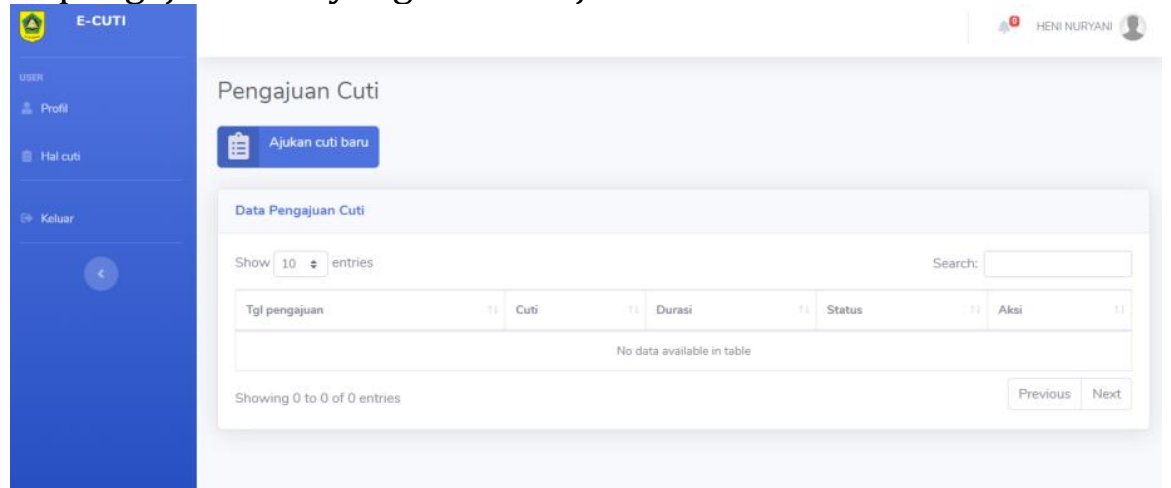

Gambar 6. Implementasi Halaman Pengajuan Cuti Pegawai

Penerapan Website Sistem Pengajuan Cuti Pegawai (Susi Susilowati) | 333 
Jurnal Sains Komputer \& Informatika (J-SAKTI)

Volume 3 Nomor 2 September 2019, pp. 327-336

ISSN:2548-9771/EISSN:2549-7200

http://tunasbangsa.ac.id/ejurnal/index.php/jsakti

2. Halaman Notifikasi

Halaman ini berfungsi untuk memunculkan notifikasi perihal status pengajuan cuti.

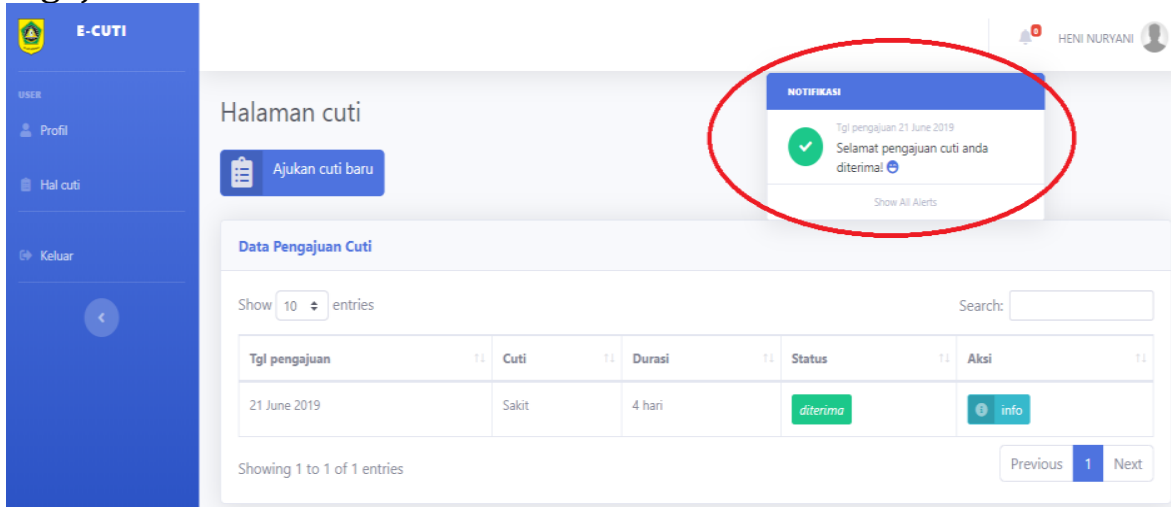

Gambar 7. Implementasi Halaman Notifikasi

B. Implementasi halaman Admin Website

1. Halaman Beranda Admin

Halaman ini berfungsi untuk melihat Total User dan Permintaan Pengajuan Cuti dari pegawai.

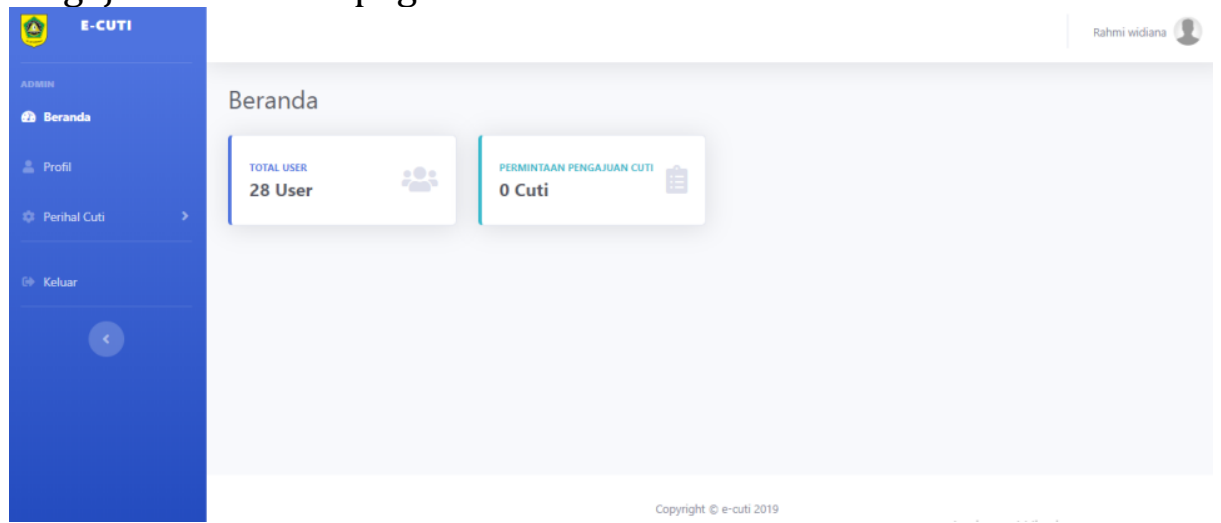

Gambar 8. Implementasi Halaman Beranda Admin

2. Halaman Pengajuan Data Cuti

Halaman ini berfungsi untuk melihat data dan merubah status pengajuan cuti yang telah diajukan untuk selanjutnya diproses di halaman proses cuti. 


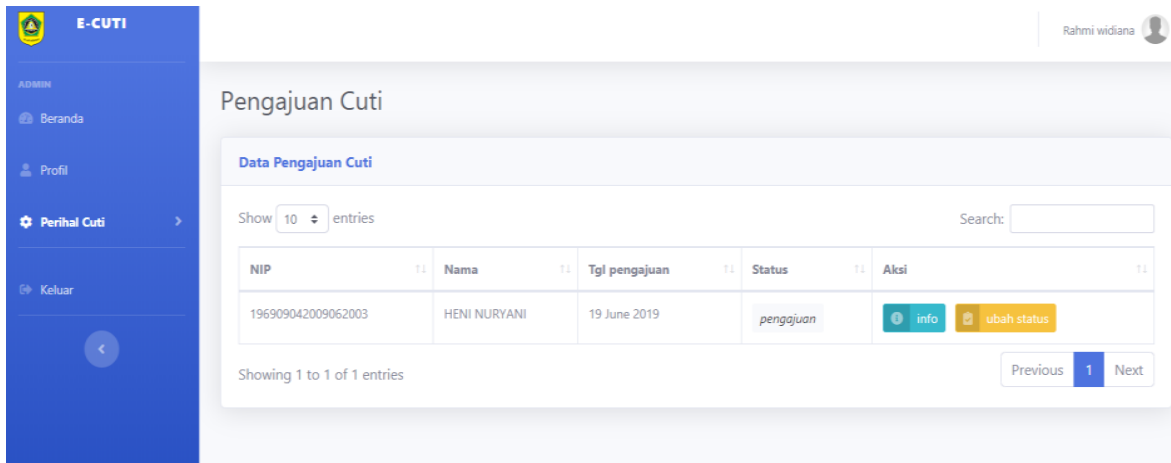

Gambar 9. Implementasi Halaman Pengajuan Cuti

3. Halaman Persetujuan Cuti

Halaman ini befungsi untuk memproses pengajuan cuti yaitu dengan merubah status dan mencetak laporan pengajuan cuti apabila telah disetujui.

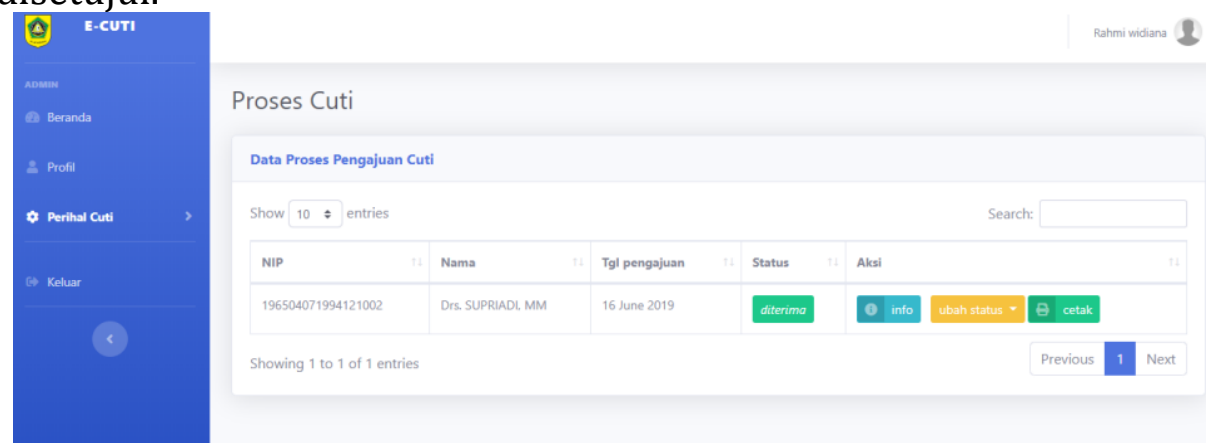

Gambar 10. Implementasi Halaman Persetujuan Cuti

\section{SIMPULAN}

Berdasarkan hasil analisa dan rancangan yang sudah dilakukan maka dapat disimpulkan sebagai berikut:

a) Aplikasi website pengajuan cuti pegawai ini dapat memberikan kemudahan bagi pegawai dan admin dalam memproses pengajuan cutinya kapan saja dan dimana saja.

b) Aplikasi website pengajuan cuti pegawai ini juga mampu memberikan informasi baru seputar status pengajuan cuti yang telah diajukan dan juga sebagai layanan jasa dan informasi sehingga pegawai tidak perlu meminta atau mendatangi bagian operator kepegawaian secara langsung.

\section{DAFTAR PUSTAKA}

[1] Syaripudin, G. A., Cahyana, R., "Pengembangan Aplikasi Web Untuk Pengajuan Cuti Pegawai Secara Online”, Journal STT-Garut, Vol.12 No.1, Hal.8, 2015.

[2] Arif Setiyanto \& Febriliyan Samopa, "Pembuatan Sistem Informasi Cuti pada Kantor Pelayanan Perbendaharaan Negara dengan Menggunakan PHP dan MySQL", Jurnal Tehnik Pomits, Vol.2 No.2, Hal.381-384, 2013. 
Jurnal Sains Komputer \& Informatika (J-SAKTI)

Volume 3 Nomor 2 September 2019, pp. 327-336

ISSN:2548-9771/EISSN:2549-7200

http://tunasbangsa.ac.id/ejurnal/index.php/jsakti

[3] Susanto, R., \& Andriana, A. D, "Perbandingan Model Waterfall Dan Prototyping", Majalah Ilmiah UNIKOM, 14(1), Hal.41-46, 2016.

[4] Sukamto, Rosa A., \& Muhammad Shalahuddin, "Rekayasa Perangkat Lunak", Informatika, Bandung, 2014.

[5] Akil, I., "Referensi Dan Panduan UML 2.4 Singkat Tepat Jelas", 2018.

[6] Aditiyawarman, D., "Implementasi Problem Based Learning Untuk Meningkatkan Kemampuan Mahasiswa Dalam Merancang Basisdata", Jurnal Informatika UBSI, Vol.3 No.2, Hal.277-289, 2016. 